\title{
Erratum: Iridates from the molecular side
}

Kasper S. Pedersen, Jesper Bendix, Alain Tressaud, Etienne Durand, Høgni Weihe, Zaher Salman, Thorbjørn J. Morsing, Daniel N. Woodruff, Yanhua Lan, Wolfgang Wernsdorfer, Corine Mathonière, Stergios Piligkos,

Sophia I. Klokishner, Serghei Ostrovsky, Katharina Ollefs, Fabrice Wilhelm, Andrei Rogalev \& Rodolphe Clérac

Nature Communications 7:12195 doi: 10.1038/ncomms12195 (2016); Published 20 Jul 2016; Updated 31 Aug 2016

The original version of this Article contained an error in which the first affiliation was incorrectly given as 'CNRS, ICMCB, UPR 9048, Pessac 33600, France'. This has now been corrected in both the PDF and HTML versions of the Article.

(c) (i) This work is licensed under a Creative Commons Attribution 4.0 International License. The images or other third party material in this article are included in the article's Creative Commons license, unless indicated otherwise in the credit line; if the material is not included under the Creative Commons license, users will need to obtain permission from the license holder to reproduce the material. To view a copy of this license, visit http://creativecommons.org/licenses/by/4.0/

(C) The Author(s) 2016 